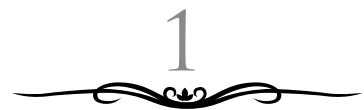

\title{
PERAN PERPUSTAKAAN DALAM MENINGKATKAN \\ KUALITAS MAHASISWA DENGAN BERBAGAI LATAR BELAKANG BUDAYA
}

\author{
Saliyo \\ STAIN Kudus, Jawa Tengah, Indonesia \\ anis_ulum@yahoo.co.id
}

\begin{abstract}
LIBRARY OF ROLE IN IMPROVING THE QUALITY OF STUDENTS WITH VARIOUS CULTURAL BACKGROUND: This article was written aims to determine the role of libraries in contributing quality of students studying at the college. Writing this article is the result of the exploration of literature supporting the role of libraries improve the quality with different cultural backgrounds. The writing method of analysis of the literature found a writer with deductive and inductive approach. Exploration results showed that one of the supporting facilities in the quality of learning in college is a role in a library. Provision of libraries contribute to the implementation of the three responsibilities of the college. One of these is the provision of organizational support and provide services to library users were friendly and polite. The library is a dynamic space to build works of human civilization. The progress of culture and civilization of a nation can not be separated from the state of progress of the existing library. The progress and setbacks of a nation lies on its library. Like the life of the library is the heart.
\end{abstract}

Keywords: Libraries, Student, Culture. 


\begin{abstract}
Abstrak
Artikel ini ditulis bertujuan untuk mengetahui peran perpustakaan dalam memberikan konstribusi kualitas mahasiswa yang belajar di Perguruan Tinggi. Tulisan artikel ini merupakan hasil dari eksplorasi literatur yang mendukung peran perpustakaan meningkatkan kualitas dengan berbagai latar belakang budaya. Metode penulisan analisis dari literatur yang ditemukan penulis dengan pendekatan deduktif dan induktif. Hasil eksplorasi menunjukan bahwa salah satu fasilitas pendukung kualitas dalam belajar di Perguruan Tinggi adalah peran yang ada pada perpustakaan. Penyediaan perpustakaan turut mendukung pelaksanaan Tridharma Perguruan Tinggi. Salah satu dukungan tersebut adalah penyediaan pengorganisasian dan memberikan pelayanan kepada pengguna perpustakaan yang ramah dan santun. Perpustakaan merupakan ruang yang dinamis yang dapat membangun karya-karya perdaban manusia. Kemajuan budaya dan peradaban suatu bangsa tidak lepas dari keadaan kemajuan perpustakaan yang tersedia. Kemajuan dan kemunduran suatu bangsa terletak pada perpustakaan yang dimilikinya. Ibarat kehidupan perpustakaan merupakan jantungnya.
\end{abstract}

Kata Kunci: Perpustakaan, Mahasiswa, Budaya.

\title{
A. Pendahuluan
}

Undang-Undang Republik Indonesia Nomor 43 tahun 2007 tentang perpustakaan pada pasal 5 ayat 1 menjelaskan bahwa: (1) masyarakat memiliki hak yang sama untuk memperoleh layanan serta memanfaatkan dan mendayagunakan fasilitas perpustakaan; (2) mengusulkankeanggotaan Dewan Perpustakaan;(3) mendirikan dan /atau menyelenggarakan perpustakaan; (4) berperan serta dalam pengawasan dan evaluasi terhadap penyelenggaraan perpustakaan. Selanjutnya pasal 2 menyatakan bahwa masyarakat di daerah terpencil, terisolasi atau terbelakang sebagai akibat faktor geografis berhak memperoleh layanan perpustakaan secara khusus. Pasal 3 lebih menjelaskan tentang perlindungan 
dan penyediaan fasilitas pada anak berkebutuhan khusus. Pasal tersebut menyatakan bahwa masyarakat yang memiliki cacat dan/ atau kelainan fisik, emosional, mental, intelektual, dan/atau sosial berhak memperoleh layanan perpustakaan yang disesuaikan dengan kemampuan dan keterbatasan masing-masing.

Paparan di atas dapat disimpulkan bahwa pemerintah telah menjamin pada masyarakat untuk mendapatkan layanan perpustakaan. Dimana tempat berada pemerintah akan memiliki kewajiban menyediakan layanan perpustakaan. Hal yang lebih penting lagi bahwa pemerintah juga memperhatikan kebutuhan perpustakaan pada anak yang memiliki kebutuhan khusus. Penyediaan layanan ini sesuai dengan kemampuan dan kebutuhan khusus anak baik fasilitas gedung ataupun materi buku yang dibutuhkannya.

Perpustakaan merupakan salah satu pelestari bahan pustaka sebagai budaya. Perpustakaan memiliki fungsi sebagai sumber informasi ilmu pengetahuan dan teknologi. Perpustakaan bertujuan untuk mencerdaskan kehidupan bangsa dan menunjang pelaksanaan pembangunan nasional. Untuk bisa menjangkau semua lapisan di masyarakat tentang layanan perpustakaan, maka dipandang perlu untuk menetapkan lembaga yang menangani perpustakaan secara nasional. Perpustakaan nasional dibentuk berdasarkan peraturan pemerintah. Perpustakaan tersebut bertugas membantu Presiden dalam penyelenggaraan pendidikan dan pengembangan dalam rangka pelestarian bahan pustaka sebagai hasil budaya bangsa ilmu pengetahuan dan teknologi dan kebudayaan. ${ }^{1}$

Persepsi masyarakat terhadap perpustakaan merupakan tempat berkumpulnya para kaum intelektual, pelajar dan dosen. Masyarakat belum memiliki budaya bahwa perpustakaan dapat dijadikan sebagai pusat sumber belajar. Hal yang demikian merupakan ketidaksadaran kolektif yang masih melekat pada masyarakat. Secara tidak sadar perilaku demikian merupakan

1 Purwono dan S. Suharmini, Perpustakaan dan Kepustakawanan Indonesia (Jakarta: Universitas Terbuka, 2009), hlm. 2-20. 
warisan dari masyarakat terdahulu. Masalahnya ketika masa hidupnya tidak mendapati perpustakaan berperan terhadap perubahan sosial masyarakat. $^{2}$

Hal yang lain yang tidak dapat dilupakan adalah masyarakat Perguruan Tinggi. Perguruan Tinggi memiliki kewajiban mendidik anak didik untuk menjadi ilmuwan, bangsawan, praktisi ilmu pengetahuan tertentu, maka Perguruan Tinggi secara moral dituntut berperan aktif untuk menyediakan fasilitas buku dan layanan yang ramah. Salah satu fasilitas penunjuang prestasi perguruan tunggi berada pada perpustakaan. Perpustakaan merupakan pendukung keberhasilan suatu Perguruan Tinggi melalui penyediaan perpustakaan yang turut melaksanakan Tridharma Perguruan Tinggi dengan penyediaan pengorganisasian dan memberikan pelayanan kepada pengguna perpustakaan.

Menurut Zeithaml dan Berry bahwa kualitas pelayanan adalah perbandingan antara pelayanan yang diharapkan konsumen dengan pelayanan yang diterimanya. Lebih sederhannya bahwa pelayanan yang diterima dengan sesuai yang diharapkan, maka kualitas pelayanan dikatakan baik dan memuaskan. Jika pelayanan melebihi dari harapan konsumen, maka pelayanan perpustakaan tersebut memasuki ideal. ${ }^{3}$

Penjelasan di atas dapat disimpulkan bahwa perpustakaan memiliki peran yang sangat vital dalam membangun perubahan sosial budaya masyarakat. Perpustakaan juga berperan untuk mencerdaskan putra-putri bangsa di Perguruan Tinggi. Alasannya karena perpustakaan merupakan sumber informasi dan teknologi. Perpustakaan dapat menunjang Tridharma Perguruan Tinggi. Sisi lain pelayanan perpustakaan yang berkualitas merupakan harapan dari konsumen. Pelayanan yang sesuai dengan harapan konsumen

2 Darmaningtiyas, Perpustakaan dalam Dinamika Pendidikan dan Kemasyarakatan, ed. F.A. Wiranto (Semarang: Universitas Katolik Soegijapranata, 2008), hlm. 76.

${ }^{3}$ Samosir dan Zurni Zahara, "Pengaruh Kualitas Pelayanan terhadap Kepuasan Mahasiswa Menggunakan Perpustakaan USU”, Jurnal Studi Perpustakaan dan Informasi, Vol. 1, No. 1, Juni 2005, hlm. 28. 
merupakan layanan yang memuaskan. Lebih meningkat lagi pelayanan yang melebihi dari harapan konsumen adalah layanan yang ideal.

\section{B. Pembahasan}

\section{Jenis Perpustakaan dalam Masyarakat}

\section{a. Jenis-jenis Perpustakaan}

Apabila kita mencermati keberadaan perpustakaan yang ada dalam masyarakat kita dapat mengklasifikasikan beberapa jenis perpustakaan. Ada lima jenis perpustakaan yang ada dalam masyarakat. Pertama perpustakaan nasional. Sampai hari ini belum ada kesepahaman tentang definisi perpustakaan nasional. Hanya saja ada kesepahaman tentang fungsi dari perpustakaan nasional. Fungsi perpustakaan nasional adalah menyimpan semua bahan pustaka yang tercetak dan terekam yang diterbitkan pada suatu Negara.

Kedua perpustakaan umum. Perpustakaan umum memiliki tugas melayani umum atau semua anggota lapisan masyarakat yang memerlukan jasa perpustakaan tentang informasi. Ciriciri perpustakaan umum memberikan layanan terbuka untuk umum, dibiayai oleh dana umum, dan jasa yang diberikan bersifat cuma-cuma. Menurut Blasius bahwa perpustakaan amat penting bagi kehidupan budaya dan kecerdasan bangsa. Masalahnya perpustakaan umum merupakan gerbang menuju pengetahuan, mendukung perorangan, dan kelompok untuk melakukan kegiatan belajar seumur hidup, pengambilan keputusan mandiri dan pembangunan budaya.

Ketiga perpustakaan sekolah. Perpustakaan sekolah merupakan unit pelayanan di dalam lembaga sekolah. Kehadirannya hanya dapat dibenarkan jika mampu membantu pencapaian pengembangan tujuan-tujuan sekolah yang bersangkutan. Tujuan perpustakaan sekolah lebih pada penekanan pendidikan dan rekreatif budaya. Keempat perpustakaan Perguruan Tinggi. Perpustakaan Perguruan Tinggi merupakan unit pelaksana teknis Perguruan Tinggi bersama dengan unit lain. Perpustakaan 
Perguruan Tinggi turut melaksanakan tridarma Perguruan Tinggi bersama dengan unit lain dengan cara memilih, menghimpun, mengolah, merawat, serta melayangkan sumber informasi kepada lembaga induknya. Kelima perpustakaan khusus. Perpustakaan khusus merupakan perpustakaan yang memiliki koleksi pada subjek-subjek khusus. Tugas perpustakaan khusus di antaranya adalah memberi informasi pada badan induk, dimana perpustakaan tersebut berada. Tempatnya di gedung-gedung pusat penelitian. Melayani pemakai khusus pada organisasi induk. Cakupan subjek terbatas. Ukuran perpustakaan dan koleksinya relatif kecil. ${ }^{4}$

Artikel ini mengkaji tentang peran perpustakaan Perguruan Tinggi dalam memajukan mahasiswanya. Menurut Sulistiyo dan Basuki perpustakaan Perguruan Tinggi memiliki tujuan: (1) Memenuhi keperluan informasi masyarakat Perguruan Tinggi, lazimnya staf pengajar dan mahasiswa dan tenaga kerja administrasi: (2) Menyediakan bahan pustaka pada semua tigkatan akademis: (3) Menyediakan ruang belajar bagi pemakai perpustakaan; (4) Menyediakan jasa peminjaman bagi pemakai perpustakaan; (5) Menyediakan jasa informasi aktif yang tidak saja terbatas pada lingkungan Perguruan Tinggi, tetapi juga bagi industri lokal. ${ }^{5}$

Apapun jenisnya perpustakan, ia memiliki tugas memberikan layanan informasi ilmu pengetahuan dan teknologi. Tujuannya untuk mencerdaskan warga Negara serta membentuk karakter yang berbudi luhur. Di antara peran perpustakaan Perguruan Tinggi adalah memberikan fasilitas kepada mahasiswa dan dosen untuk menigkatkan kualitas ilmu pengetahuan dibidangnya masing-masing.

\section{b. Promosi Perpustakaan dalam Masyarakat Kampus}

Pengalaman pengetahuan seseorang salah satu cara mendapatkannya adalah dengan cara membaca. Membaca dalam Islam dikenal dengan falsafah iqra' (baca). Seseorang yang mau membaca akan mendapatkan pengetahuan, walaupun kecil.

${ }^{4}$ Purwono dan S. Suharmini, Perpustakaan, hlm. 8-17.

${ }^{5}$ Triana dan Santi, "Analisis Kebutuhan Pengguna Perpustakaan IAIN SU”, Jurnal Iqra, Vol. 7, No. 1 Mei 2013, hlm. 81. 
Bahan bacaan seseorang bisa didapatkan dalam bentuk tulisan atau buku yang tercatat secara sistematis. Sisi lain seseorang juga dapat mendapatkan pengetahuan melalui membaca kebesaran dan kekuasaan Allah. Cara yang kedua adalah cara yang ditempuh oleh orang-orang yang beriman dan mau memanfaatkan akalnya.

Membaca dalam bentuk tulisan yang terbukukan dapat ditemukan di toko-toko buku atau perpustakaan. Mendapatkan pengetahuan paling mudah dan murah biayanya dapat ditemukan di tempat-tempat perpustakaan. Perpustakaan merupakan sumber ilmu pengetahuan. Masyarakat yang ingin mendapatkannya dapat memanfaatkan perpustakaan. Masyarakat yang senang mengenal dan mau memanfaatkan perpustakaan dapat dipastikan masyarakat yang kaya dengan pengetahuan.

Pekerjaan yang utama untuk dilaksanakan oleh semua orang yang memiliki kewenangan dan mau memikirkan permasalahan tersebut adalah bagaimana cara setiap orang mengenal perpustakaan dan mau memanfaatkannya. Jawaban yang paling sederhana masyarakat mengetahui pentingnya perpustakaan dalam kehidupannya. Pemasyarakatan perpustakaan merupakan suatu upaya untuk memperkenalkan memberi pengertian, dan memberi dorongan kepada masyarakat untuk meningkatkan pemanfaatan perpustakaan melalui kekayaan koleksi yang ada di perpustakaan. ${ }^{6}$

Menurut Thaher Shah Sri Maradjo pemasyarakatan perpustakaan adalah usaha-usaha atau tindakan yang dilakukan untuk memberikan dorongan penggalakan atau bantuan memajukan perpustakaan. Memberikan dorongan berarti memberikan motivasi pada petugas pengelolaan perpustakaan untuk dilakukan pelayanan dengan secara ramah dan nyaman. Sisi lain dorongan juga diberikan kepada masyarakat untuk gemar berkunjung ke perpustakaan membaca buku. Pemberian bantuan

${ }^{6}$ Sudarsana dan Bastiano, Pembinaan Minat Baca (Jakarta: Universitas Terbuka, 2009), hlm. 342. 
dapat diberikan pada perpustakaan dalam bentuk perangkat keras hardware ataupun perangkat lunak software. ${ }^{?}$

Memang perpustakaan harus dikenal masyarakat. Alasannya, karena perpustakaan sangat penting untuk membangun masyarakat yang kreatif dan inovatif. Perpustakaan perlu membangun pelayanan dan fungsi yang berorientasikan pada people approach. Hal tersebut dilakukan agar masyarakat tertarik pada perpustakaan. Perpustakaan merupakan sumber pengajaran, penyelidikan, informasi. Perpustakaan dapat membantu masyarakat untuk berkreatif dan berinofasi dalam hidupnya. ${ }^{8}$

Perkembangan teknologi informasi yang pesat diharapkan masyarakat dapat memperoleh layanan informasi yang layak, ramah dan nyaman untuk memperoleh layanan perpustakaan. Hal demikian masyarakat mampu berbuat kreatif dan inovatif untuk membangun kehidupannya. Masyarakat yang mau memanfaatkan perpustakaan masyakat menjadi cerdas, berpengetahuan dan memiliki visi untuk maju dalam derap langkah kehidupannya. ${ }^{9}$

Disamping perpustakaan memiliki peran mencerdasakan masyarakat, perpustakaanjuga mendukung adanya kemajuan dalam pendidikan. Pendidikan memerlukan dukungan yang besar dari kelengkapan dan layanan perpustakaan yang memadai. Tentunya perpustakaan tidak hanya sekedar sebagai tempat menitipkan hasil karya pemikiran seseorang. Perpustakaan apabila demikian, dan tidak ada manusia yang berkunjung memanfaatkannya, perpustakaan menjadi tempat yang bisu dan mati. Ruh perpustakaan menjadi spirit inovasi dan kreatif manusia menjadi mandul. Menjawab persoalan tersebut perpustakaan harus mampu dikenal oleh setiap orang. Perpustakaan memberikan layanan yang ramah dan nyaman. Perpustakaan menyediakan informasi yang

\section{${ }^{7}$ Ibid., hlm. 342.}

${ }^{8}$ Z.M. Nor dan R. Yusuf, "Peranan Perpustakaan dalam Pembentukan Masyarakat yang Kreatif dan Berinovasi”, http://www.myideas.my/, diakses pada 13 Desember 1015, hlm. 4.

${ }^{9}$ Ibid., hlm. 7. 
kekinian agar dapat memberikan jawaban tantangan jaman setiap anggota masyarakat.

Perpustakaan merupakan ruang yang dinamis yang dapat membangun karya-karya perdaban manusia. Perpustakaan merupakan nafas kehidupan dari tumbuh suburnya ilmu pengetahuan yang dapat mendorong kehidupan yang maju bagi yang memanfaatkanya. Imam Ali Khoemeni menyatakan semoga ada suatu masa senjata-senjata berubah menjadi pena. Sebab senjata hanya akan banyak digunakan untuk membunuh, sedangkan pena akan menghidupkan kemanusiaan. Pena memiliki fungsi mengawetkan pemikiran dan dapat diwariskan. Hasil pemikiran manusia yang tergoreskan dalam tulisan menjadi karya peradaban manusia yang rasional. Karya karya tersebut dapat diwariskan dari generasi ke generasi.

Hasil penelitian menunjukan bahwa budak-budak Aljazair setiap bertambah ilmu pengetahuannya dalam kemampuan baca tulis dan pengetahuan lainnya wajah mereka ketika difoto menjadi berseri-seri, indah dan percaya diri. Hasil penelitian tersebut menunjukan bahwa ada korelasi antara bertambahnya ilmu pengetahuan seseorang terhadap penampilan wajah yang berseriseri, indah dan percaya diri. ${ }^{10}$

Untuk dapat melayani masyarakat dengan ramah, nyaman dan menyenangkan, maka dijelaskan dalam Undang Undang Republik Indonesia Nomor 43 tahun 2007 tentang perpustakaan pasal 2. Perpustakaan diselenggarakan berdasarkan asas pembelajaran sepanjang hayat, demokrasi, keadilan, keprofesionalan, keterbukaan, keterukuran dan kemitraan. Pasal 3 berbunyi perpustakaan berfungsi sebagai wahana pendidikan, penelitian, pelestarian, informasi, dan rekereasi untuk meningkatkan kecerdasan dan keberdayaan bangsa. Pasal 4 berbunyi perpustakaan bertujuan memberikan layanan kepada pemustaka, meningkatkan kegemaran membaca, serta memperluas wawasan dan pengetahuan untuk mencerdaskan kehidupan bangsa.

${ }^{10}$ E. Setyowardani, “Membangun Budaya Perpustakaan”, Gemari, Edisi 106, Tahun X, 2009, hlm. 66. 
Untuk mendukung pemasyarakatan perpustakaan perlu ada dukungan dari para pustakawan. Menghadapi perubahan zaman, pustakawan dituntut memiliki kemampuan untuk melihat dengan jelas apa yang sesunguhnya yang terjadi dalam perubahan masyarakat. Keinginan apa yang diharapkan dalam masyarakat berkaitan dengan perpustakaan. Inovasi evaluasi profesi pustakawan terus diperbaharui seiring dengan tuntutan zaman. Pembaharuan pelayanan perlu diterjemahkan dalam operasi layanan perpustakaan setiap waktu. Pelayanan yang bersifat cetak tidaklah cukup memadai di era teknologi sekarang. Pelayanan berbasis elektronik menjadi keharusan perpustakaan di era teknologi internet. ${ }^{11}$

Penjelasan di atas dapat dipahami bahwa perpustakaan dalam masyarakat ada beberapa hal yang perlu dipersiapkan. Pertama perpustakaan memberikan pelayanan yang ramah, nyaman. Kedua perpustakaan menyediakan informasi yang kekinian yang dapat menjawab permasalahan zaman. Ketiga kompetensi tenaga-tenaga pustakawan selalu diperbaharui seiring dengan perkembangan zaman.

Sisi lain perpustakaan juga tidak hanya dikenal di kampus, tetapi perpustakaan merupakan denyut jantungnya masyarakat kampus. Paling tidak mahasiswa dan dosen akrab dengan, menikmati nafasnya peradaban yang ada di perpustakaan. Hal yang demikian perpustakaan ikut berperan untuk meningkatkan kualitas mahasiswa dan dosen dalam kegiatan akademiknya.

\section{Perpustakaan dalam Lingkaran Budaya}

Kemajuan budaya dan peradaban suatu bangsa tidak lepas dari keadaan kemajuan perpustakaan yang tersedia dalam bangsa tersebut. Ruh kemajuan suatu bangsa terletak pada perpustakaan yang dimilikinya. Ibarat kehidupan perpustakaan merupakan sumbernya atau jantungnya. Ada sebuah pepatah mengatakan " $A$ book is like garden carried in the pocket." Buku ibarat taman yang

${ }^{11}$ A.R. Siregar, Perpustakaan: Energi Pembangunan Bangsa (Sumatara: Universitas Sumatra Utara Press, 2004), hlm. 71-72. 
selalu ada dalam kantong. Setiap kali dapat dibaca atau dikeluarkan ketika dibutuhkannya. Buku ibarat pohon yang selalu berbuah. Buah tersebut selalu dipetik untuk dimanfaatkannya.

Perpustakaan merupakan sumber khazanah peradaban. Ada beberapa alasan perpustakaan dapat dijadikan sumber khazanah peradaban. Pertama perpustakaan merupakan mata rantai yang menghubungkan dengan sejarah, yaitu karya batin berupa karya sastra, filsafat, teknologi dan peristiwa sejarah lainnya. Sebagai contoh apabila pemikiran Ibnu Sina sebagai dokter tidak terdapat dalamperpustakaan, makatransformasipengetahuan penemuannya akan hilang. Kedua perpustakaan memberikan informasi sebagai kebutuhan saat ini. Temuan temuan yang dibukukan akan memberikan manfaat bagi generasi selanjutnya. Ibarat ada dua orang atau lebih saling bertukar apel, maka akan dapat apel, tetapi apabila seseorang bertukar ilmu pengetahuan, akan dapat lebih. Ketiga perpustakaan dapat membimbing untuk melangkah lebih maju ke masa depan. Perpustakaan merupakan fasilitas bersama untuk menopang kemajuan bagi yang membacanya. $\frac{12}{-}$

Kata budaya dalam bahasa inggris dinamakan culture. Menelisik lebih dalam kata culture berasal dari kata latin culture. Kata tersebut memiliki makna mengolah, menanami, memasang. Menurut Tylor culture memiliki makna yang sangat kompleks. Makna tersebut bahwa budaya memiliki makna pengetahuan, keyakinan, seni, moral, hukum, adat atau kebiasaan, kemampuan lain dan kebiasaan yang ada dalam suatu anggota masyarakat. Menurut Herkovits bahwa kebudayaan sesuatu yang dibuat oleh manusia dalam suatu lingkungan. Menurut Kim kebudayaan merupakan properti yang muncul pada individu dan berinteraksi dengan yang lain diatur untuk merubah lingkungan. Budaya merupakan representasi dari sesuatu hal yang digunakan oleh masyarakat secara kolektif dan alami sebagai sumber pencapaian prestasi manusia. ${ }^{13}$

${ }^{12}$ E. Setyowardani, "Membangun”, hlm. 67.

13 U. Kim, K.S. Yang, dan K.K. Hwang, Indegenous and Cultural Psychology Understanding People in Context (New York: Springer, 2006), 
Kebudayaan didefinisikan sebagai cara. Konsep kebudayaan ditampakkan dalam berbagai pola tingkah laku yang dikaitkan dengan kelompok-kelompok tertentu seperti adat atau cara hidup suatu masyarakat. Konsep kebudayaan sebagai suatu simbol yang mempunyai makna. Kebudayaan memiliki persamaan dengan pandangan interaksionalisme simbolik. Interaksi simbolik menjelaskan tingkah laku manusia yang memiliki makna. Ada tiga makna dalam interaksi simbolik dalam kebudayaan. Pertama manusia melakukan berbagai hal atas dasar makna. Kedua yang mendasari interaksi simbolik adalah makna berasal dari interaksi antara manusia yang satu dengan yang lain. Kebudayaan adalah suatu sistem makna yang dimiliki bersama, dipelajari, diperbaiki, dipertahankan, dan didefinisikan dalam konteks orang yang berinteraksi. Ketiga interaksi simbolik dimodifikasi melalui penafsiran berkaitan dengan berbagai hal yang dihadapi orang tersebut. ${ }^{14}$

Apabila mencermati definisi di atas kebudayan dalam perpustakaan merupakan sesuatu hal yang dasar yang dapat dijadikan modal untuk membangun kemajuan peradaban manusia pada suatu lingkungan. Alasannya, karena kebudayaan memiliki makna pengetahuan, kebiasaan interaksi antara manusia secara individu apa yang dimilikinya dengan yang lain. Budaya merupakan sumber pencapaian prestasi manusia. Perpustakaan merupakan sumber kemajauan manusia. Perpustakaan merupakan sumber peradaban manusia. Perpustakaan juga merupakan media interaksi simbolik pengguna yang haus akan pengetahuan. Simbolsimbol yang ada dalam perpustakaan yang berinteraksi antara satu dengan yang lain hanyalah dua kata "ilmu dan informasi." Ilmu dan informasi menjadi tujuan utama seseorang berkunjung ke perpustakaan. Ilmu dan informasi merupakan modal utama seseorang untuk maju dan berkarya.

hlm. 11.

${ }^{14}$ J.P. Spradley, Metode Etnografi (Yogyakarta: Mutiara Wacana, 2006), hlm. 5-7. 
Perpustakaan merupakan sumber yang sangat vital untuk membangun sebuah budaya manusia. Fungsi pelayanan pustakawan menyediakan pelayanan yang inovatif dan kreatif bagi masyarakat untuk menyelesaikan permasalahan kehidupannya. Tuntutannya adalah perpustakaan menyediakan pelayanan yang bermutu dan menyediakan koleksi bahan rujukan, infrastruktur yang kondusif sesuai dengan kebutuhan pengguna. ${ }^{15}$

Sebagai penyokong perkembangan kemajuan peradaban manusia suatu bangsa perpustakaan mempunyai pekerjaan rumah yang tidak kecil. Hal tersebut seiring dengan perkembangan informasi dan teknologi. Pekerjaan rumah perpustakaan dapat dilihat secara makro maupun mikro agar berperan memajukan peradaban manusia. Secara makro pekerjaan rumah perpustakaan adalah masyarakat sebagai pengguna perpustakaan. Secara mikro pekerjaan rumah perpustakaan adalah perpustakaan itu sendiri. Pelayanan perpustakaan yang ramah nyaman serta koleksi yang dapat memenuhi kebutuhan pengguna dan fasilitas informasi teknologi yang memadai. ${ }^{16}$

Ada beberapa tantangan perpustakaan sebagai sumber untuk membangun kebudayaan suatu bangsa. Pertama perpustakaan berorientasi pada pengguna (misal mahasiswa, siswa, masyarakat umum, dan lain-lain). Artinya siapa penggunanya, maka kelengkapan buku dan pelayanan berorientasi pada pengguna perpustakaan dimana perpustakaan tersebut berada. Kedua manajemen perpustakaan menggunakan manajemen yang akuntabel. Hasil seseorang memanfaatkan perpustakaan memang tidak begitu kelihatan produknya. Paling tidak pengguna merasa terbantu secara pekerjaan dan tugas-tugasnya dalam menyelesaikannya. Ketiga perpustakaan mendukung kebutuhan publik. Artinya secara ekonomi budaya perpustakaan dapat mendukung atau memberikan informasi dua hal tersebut. Keempat perpustakaan bekerjasama dengan perpustakaan yang lain. Hal tersebut dilakukan agar saling melengkapi kebutuhan

\footnotetext{
${ }^{15}$ Z.M. Nor, dan R. Yusuf, "Peranan”, hlm. 6.

${ }^{16}$ A.R. Siregar, Perpustakaan, hlm. 3-4.
} 
pengguna. Kelima perpustakaan berkaitan dengan kewirausahaan. Perpustakaan dapat menjadi pendukung adanya kreativitas pengguna untuk menjadi wirausaha.

Apabila dikaji mendalam paparan di atas, perpustakan memiliki keterkaitan yang erat dengan kebudayaan suatu bangsa. Kemajuan manusia suatu bangsa karena orang tersebut gemar membaca. Sumber bacaan yang murah mudah terjangkau adalah perpustakaan. Perpustakaan sebagai ruh kemajuan manusia suatu bangsa dituntut untuk siap memberikan layanan yang ramah nyaman dan memenuhi kebutuhan informasi yang berbasis teknologi dan berbasis manual. Perpustakaan merupakan mitra pembangunan kebudayaan suatu bangsa.

\section{Perilaku Pengguna Perpustakaan Berkaitan dengan Self dalam Ilmu Psikologi Lintas Budaya}

Tema self(diri) dalam ilmu psikologi merupakan kajian yang sudah lama. Sisi lain self juga banyak dikaji dalam ilmu sosiologi dan antropologi. Sudah diakui bahwa self telah dikaji sebagai bagian interaksi manusia dalam kelompok. Bagaimanapun banyak variasi tentang self dalam kajian lintas budaya. Secara khusus self sangat menentukan dalam perilaku sosial manusia. Sisi lain self berbeda dengan budaya yang tidak dapat berkembang. Hal yang paling penting kajian self dalam kajian psikologi lintas budaya ada tiga hal. Pertama aspek dari self itu sendiri. Kedua variasi dimensi self berkaitan dengan konteks budaya. Ketiga keterkaitan antara budaya dan self.

Menurut Cooley bahwa self berkaitan dengan self itu sendiri. Makna kata self dalam bahasa Inggris meliputi kata I, My, Mine, dan Myself. Secara lebih luas self memiliki makna berkaitan dengan aspek motivasi sosial yang berkaitan dengan diri. Sebagai contoh self memiliki makna sikap. Saya suka dia. Self memiliki makna keyakinan. Contohnya saya yakin A hasil dari B. Self memiliki makna intensitas. Contohnya saya merencanakan untuk mengerjakan ini dengan baik. Self memiliki makna norma. Contohnya dalam kelompok saya setiap orang harus bekerja sesuai 
dengan aturan. Self memiliki makna peran. Contohnya dalam keluarga saya ayah berperan sebagai pemimpin. Self memiliki makna nilai. Contohnya saya pikir keseimbangan memiliki peran yang sangat penting. ${ }^{17}$

Self berkaitan dengan budaya. Menurut Marsella bahwa secara jelas self berkaitan dengan variasi budaya. Bagaimanapun self berkaitan dengan variasi budaya. Ada tiga dimensi yang terkandung dalam makna self berkaitan dengan budaya. Pertama self berkaitan dengan kompleksitas budaya. Ada perbedaan antara kompleksitas budaya dengan lintas budaya. Perbedaan tersebut terjadi pada 1500 tahun yang lalu di kota-kota metropolitan. Menurut ilmu arkeologis bahwa setiap kelompok manusia paling tidak memiliki anggota 30 individu. Setiap kelompok terdiri dari 30 individu bahkan lebih tanpa batas. Setiap kelompok memiliki cara berhubungan yang sangat kompleks. Cara cara mereka bertani, bertukar barang, transportasi hubungan dan memiliki kedudukan sosial yang berbeda-beda. Kompleksitas budaya dalam pengukurannya memiliki variasi domain. Variasi domain tersebut meliputi bahasa, teknologi, ekonomi, politik, budaya, sistem pendidikan, religiusitas, struktur sosial dan lain sebagainya.

Self juga berkaitan dengan budaya. Budaya adalah suatu ingatan seseorangyang terdapat dalam suatu komunitas masyarakat. Budaya secara spesifik didesain untuk melakukan kehidupan yang lebih efektif di masa lalu. Budaya juga berkaitan dengan masalah yang dihadapi oleh manusia dalam situasi sosial, untuk berpikir tentang diri dan perilaku sosial serta memperkuat yang sudah ada di masa lalu. Budaya juga merupakan simbol sebagai fasilitas dalam interaksi manusia, berperan dalam pekerjaan manusia masa lalu.

Budaya berkaitan dua hal, yaitu dengan individu dan kolektif. Keduanya menekankan pada self reliance (kepercayaan diri), kemandirian, temuan-temuan diri seseorang, dan aktualisasi diri. Sebagai individu self berkaitan untuk meningkatkan kompleksitas diri, privasi diri sebab dalam diri banyak variasi yang

${ }^{17}$ H.C. Triandis, “The Self and Social Behavior in Differing Cultural Contexts, Psychological Review”, Vol. 96, No. 3, 1989, hlm. 506. 
dimiliki seseorang. Sisi lain self berkaitan dengan kolektivitas. Sebaliknya kolektivitas dalam kajian budaya memiliki fungsi memperbesar pentingnya budaya kolektif dan kolektivitas dalam budaya diri yang dapat menjadikan sampel dalam yang menunjukan kolektivitas seseorang. ${ }^{18}$

Menurut Fang, self dapat menjadikan seseorang dalam berbagai perspektif. Budaya di China, self dapat menunjukan kepribadian seseorang. Ini merupakan perspektif baru bahwa self menunjukan kepribadian seseorang. Hal yang demikian dalam psikologi ada kepercayaan diri, aktualisasi diri,dan konsep diri. Self merupakan konsep pusat dari kosmologi Yin dan Yang. ${ }^{19}$

Mengkaji self dalam perilaku pengunjung perpustakaan memang sesuatu hal yang menarik dalam kajian psikologi. Hal ini karena self memiliki tiga makna dalam kajian lintas budaya. Pertama self memiliki makna diri itu sendiri. Hal ini dapat diartikan bahwa seseorang yang memiliki semangat membaca atau memanfaatkan perpustakaan karena orang terebut memiliki konsep, kepercayaan, ataupun aktualisasi diri untuk memanfaatkan perpustakaan. Kedua self berkaitan dengan budaya dan self itu sendiri. Artinya bahwa budaya membaca, ataupun meluangkan waktu untuk membaca seseorang dapat terjadi karena ada pengaruh dari budaya setempat lebih luas self memiliki makna aspek motivasi sosial yang berkaitan dengan diri, keyakinan, intensitas, norma, peran, dan nilai. Makna-makna tersebut sangat menentukan seseorang untuk aktif memanfaatkan perpustakaan dengan baik tertib dan nyaman. Apabila seseorang memiliki motivasi sosial, keyakinan, intensitas, norma, peran, dan nilai dalam memanfaatkan perpustakaan, maka dalam pelaksanaannya akan terjalin antara pengunjung dan perpustakaan sebagai media tempat membaca atau sumber informasi terjadi simbiosis mutualisme. Keduanya saling membutuhkan. Perpustakaan jangan dianggap benda mati. Perpustakaan memerlukan pengunjung atau pengguna. Sisi lain,

\footnotetext{
${ }^{18}$ Ibid., hlm. 508-512.

${ }^{19}$ U. Kim, K.S. Yang, dan K.K. Hwang, “Peranan”, hlm. 343.
} 
seseorang yang haus dengan informasi dan ilmu pengetahuan membutuhkan perpustakaan.

Self dalam pandangan budaya berkaitan dua hal yaitu dengan individu dan kolektif. Seseorang yang memiliki self dalam pandangan budaya berkaitan individu. Seseorang yang memiliki self baik secara individu atau kelompok akan berimbas pada self reliance (kepercayaan diri), kemandirian, temuan-temuan diri seseorang, dan aktualisasi diri. Disisi lain self berkaitan dengan kolektivitas. Seseorang secara kolektivitas apabila memiliki self akan memperbesar pentingnya budaya kolektivitas. Artinya bahwa self baik dalam individu atau kolektif ketika seseorang berhubungan dengan pemanfaatan perpustakaan orang tersebut akan tumbuh kepercayaan diri, kemandirian, dan budaya kolektivitas pecinta pengguna perpustakaan.

\section{Pengembangan Perpustakaan Lintas Budaya}

Semua orang hidup dalam keadaan masyarakat yang berbeda-beda. Apabila dilihat dari perbedaan bahasa di dunia, paling tidak ada 6000 bahasa yang berbeda. Setiap ada perpindahan manusia akan menumbuhkan perbedaan identitas dalam setiap waktu. Begitu juga pada era modern dan dalam dunia yang global akan memicu perkembangan teknologi informasi. Perkembangan teknologi akan meningkatkan perpindahan, komunikasi, dan memudahkan menikmati transportasi. Hal demikian karena adanya kemajuan peradaban manusia. Fenomena yang demikian juga akan memicu adanya perbedaan budaya melintas wilayah manusia.

Perbedaan budaya atau budaya multikultural mengarah pada kehidupan yang harmonis dalam wajah interaksi dalam perbedaan budaya. Perbedaan budaya dalam setiap komunitas ataupun kelompok dapat berbentuk perbedaan dalam spiritual, material, intelektual, gaya hidup, sistem nilai, tradisi, dan emosional dalam suatu komunitas kelompok atau group manusia. Perbedaan budaya atau multikultural merupakan kekuatan suatu kelompok baik dalam tingkat lokal maupun global. ${ }^{20}$

${ }^{20}$ UNESCO, Universal Declaration on Cultural Diversity (International 
Perbedaan budaya juga terjadi dalam komunitas pengguna perpustakaan. Perpustakaan merupakan sumber kekuatan adanya saling menerima perbedaan di antara sesama manusia. Perbedaan tersebut dapat berupa bahasa, kulit, jenis kelamin, agama, dan ekonomi. Perpustakaan merupakan sumber pemersatu manusia dalam perbedaan. Perpustakaan merupakan sumber toleransi antar budaya yang sangat multi.

Pendit menjelaskan bahwa dalam gerakan perpustakaan komunitas membaca menghilangkan batas-batas perbedaan antar sesama manusia. Perbedaan tersebut dapat berupa agama, bahasa, kulit, gaya hidup, intelektual, dan materi. Ketika seseorang melakukan aktivitas berkunjung ke perpustakaan, maka orang tersebut telah melepaskan perbedaan yang dia miliki. Mereka siap untuk bersama-sama dengan yang lain untuk saling menghargai antar sesama pengguna perpustakaan. Disisi lain, seseorang yang datang ke perpustakaan juga menikmati kemerdekaannya. Orang datang ke perpustakaan bebas memilih membaca informasi pengetahuan yang dia kehendaki dan suka. ${ }^{21}$

Perpustakaan sebagai pilar dalam pengembangan budaya yang berbeda-beda paling tidak memiliki dua peran yang penting. Pertama perpustakaan diharapkan dapat dijadikan institusi budaya. Artinya perpustakaan dimana tempat dapat menjadi wahana pengembangan budaya dalam bentuk tulisan. Untuk menjadi institusi tersebut perpustakaan harus memiliki dan mampu menjadi fungsi produksi, menjaga, dan menyebarluaskan karya karya orang. Kedua koleksi perpustakaan diharapkan dapat menjadi memori kolektif sebuah kenangan bersama yang digunakan oleh masyarakat untuk mewarisi budaya. ${ }^{22}$

Setiap individu dalam masyarakat global berhak menerima layanan perpustakaan yang baik. Konteks lain setiap perpustakaan dapat menyajikan layanan perpustakaan dalam pandangan

Federation of Library Associations and Institutions, 2001), hlm. 1.

21 T. Umar, "Perpustakaan Sekolah dalam Menanamkan Budaya Membaca”, Khizanah al-Hikmah, Vol. 1, No. 2, 2013, hlm. 123-130.

${ }^{22}$ Ibid., hlm. 126. 
lintas budaya. Ada beberapa prinsip untuk mengembangkan perpustakan dalam layanan yang multikulural. Pertama melayani semua anggota masyarakat tanpa adanya diskriminasi walaupun ada perbedaan budaya lokal ataupun dalam lintas global. Kedua menyediakan informasi dalam bahasa dan naskah yang tepat. Ketiga menyediakan akses pelayanan yang luas terhadap materi yang dibutuhkan oleh masyarakat tersebut. Keempat menyediakan pegawai yang dapat melayani dengan menghargai dan menghormati perbedaan masyarakat pengguna perpustakaan. ${ }^{23}$

Pandangan dalam paparan di atas dapat diambil kesimpulan bahwa peran perpustkaan merupakan peran yang vital dalam membangun semangat saling menghargai dan toleransi antar budaya yang multi baik tingkat lokal ataupun global. Yang tidak kalah penting dalam membangun layanan perpustakaan yang multi budaya baik lokal ataupun global adalah keramahan dan kenyamanan pegawai dalam melayani pengguna. Menghargai dan bersikap toleransi dalam melayani pengguna yang multi budaya. Hal yang tidak bisa dilupakan adalah menyediakan kebutuhan informasi dan pengetahuan yang dibutuhkannya.

\section{Pengembangan Perpustakaan Digital Multi Budaya Lokal ataupun Global}

Perpustakaan digital atau perpustakaan elektronik dalam masa informasi teknologi merupakan tuntutan pelayanan. Ada beberapa keuntungan adanya perpustakaan layanan digital. Keuntungannya Pertama bahwa perpustakaan digital dapat diakses dimana saja yang penting ada media teknologi yang dapat mengaksesnya. Kedua tidak perlu membawa barang yang terlalu banyak atau besar untuk memanfaatkan perpustakaan tersebut. Pengguna cukup membawa alat yang dapat mengaksesnya. Ketiga perpustakaan digital tidak banyak membutuhkan ruang dan tempat. Keempat naskah-naskah perpustakaan digital lebih awet dari kerusakan.

\footnotetext{
${ }^{23}$ UNESCO, Universal, hlm. 2.
} 
Media informasi dan teknologi atau internet telah mengubah dunia informasi tanpa banyak formalitas. Kekuatan pasar menjadikan seseorang tergantung pada dunia tersebut. Menurut Kenneth Dowlin ada empat karakteristik yang dimiliki perpustakaan digital. Pertama manajemen sumber daya manusia banyak menggunakan komputer. Kedua kemampuan menghubungkan penyedia informasi dengan pencari informasi melalui saluran elektronik. Ketiga kemampuan pegawai untuk melakukan intervensi dalam transaksi elektronik ketika dibutuhkan oleh pencari informasi. Keempat kemampuan untuk menyimpan, mengorganisasi dan menstramisikan informasi kepada pencari informasi melalui saluran elektronik. ${ }^{24}$

Untuk mengembangkan perpustakaan digital paling tidak ada empat prinsip yang harus dipenuhi. Pertama pentingnya keterlibatan komunitas yang intensif dan ekstensif dalam penyelenggaraan pengembangan perpustakaan digital dalam lintas budaya. Artinya bahwa budaya merupakan bagian dari kehidupan yang dinamis. Setiap saat waktu dapat berubah dan terbuka untuk berinteraksi dengan kebudayaan yang lain yang berbeda baik lokal ataupun global. Komunitas dalam kajian ini dimaksudkan adalah setiap elemen baik tua-muda, ahli, mahasiswa, guru, pemusik, praktisi, ilmuan saling berinteraksi dalam perpustakaan dengan aktif ataupun pasif. Interaksi aktif dapat dilakukan dengan berdiskusi antar pengunjung saling bertukar pengetahuan dan pengalaman. Interaksi pasif dengan cara membaca informasi yang ada. Kedua pentingnya banyak catatan dalam berbagai tingkatan atau level. Artinya bahwa resume review dari berbagai karya ilmiah sangat penting untuk dapat dimanfaatkan oleh pengguna perpustakaan. Hal tersebut dapat digunakan untuk mendukung kreasi budaya dan ilmu pengetahuan pembaca. Ketiga pentingnya keserempakan media. Artinya ketika suatu budaya telah menjadi referensi dalam perpustakaan, akan lebih baik menyediakan yang lebih lengkap secara media. Contohnya dansa tradisional India. Referensi tersebut dengan lengkap secara media yaitu video, audio

${ }^{24}$ A.R. Siregar, Perpustakaan, hlm. 18. 
musik, audio stori dan interpretasi, teks stori dan interpretasi, terejemahan, transkip simbol-simbol variasi musik baik versi India ataupun Barat. Keempat pentingnya dasar isi dan feedback yang relefan. Artinya bahwa isi dari budaya tersebut berdasarkan pertimbangan keutamaan dari multimedia seperti warna, musik, melodi, struktur arsitektur grafisnya, dan koreografi dansa. ${ }^{25}$

Perkembangan zaman di era global sudah tidak terelakan lagi bahwa layanan perpustakaan yang multi budaya baik lokal ataupun global memang sangat perlu. Hal yang demikian karena layanan tersebut memiliki beberapa tujuan. Pertama mempromosikan kesadaran nilai-nilai positif dalam perbedaan budaya dan mengembangkan dialog budaya. Kedua memberikan harapan pada perbedaan bahasa dan memberikan rasa hormat pada bahasa ibu. Ketiga memberikan fasilitas untuk mempelajari beberapa bahasa pada anak sedini mungkin. Keempat melindungi warisan budaya dan bahasa dan memberikan dukungan ekspresi, kreasi, dan penyebaran bahasa yang relevan. Kelima mendukung tradisi oral dan warisan budaya yang tidak terawat. Keenam mendukung partisipasi seseorang dalam kelompok budaya dan latar belakang yang berbeda-beda. Ketujuh memberikan harapan pada anak-anak didik untuk mengetahui informasi digital dan menguasai informasi teknologi. Kedelapan mempromosikan perbedaan bahasa melalui internet. Kesembilan memberikan harapan pada setiap orang untuk mengakses internet secara universal, mendukung perubahan pengetahuan dalam kerangka puralisme budaya. ${ }^{26}$

Mencermati ulasan di atas dapat disimpulkan bahwa pengembangan pepustakaan digital dalam lintas budaya memang sangat penting. Alasannya karena untuk memelihara, mendukung dan memfasilitasi generasi penerus untuk mempelajarinya. Bahkan tidak hanya hal demikian saja, tetapi juga memberikan peluang anak-anak muda untuk berkreasi menciptakan budaya baru,

${ }^{25}$ S.J. Downie, Realization of Four Important Principles in Cross Cultural Digital Library Development, Originally Presented at The JCDL 03 Workshop (Cross Cultural Usability for Digital Libraries, t.t.), hlm. 1-3.

${ }^{26}$ UNESCO, Perpustakaan, hlm. 2. 
pengetahuan baru dalam kehidupan yang berbeda-beda dalam budaya dan bahasa. Sisi lain melatih anak-anak untuk menjunjung tinggi perbedaan budaya baik lokal ataupun global dengan sikap saling menghargai, toleransi serta menghormati.

\section{Simpulan}

Perpustakaan memiliki peran yang penting untuk memajukan kualitas mahasiswa dengan berbagai latar belakang budaya. Setiap warga Negara memiliki hak untuk menikmati dan menggunakan perpustakaan. Setiap orang yang datang ke perpustakaan sebagai penggguna memiliki hak yang sama dan derajatyang sama. Perpustakaan merupakan jantungnya peradaban. Perpustakaan merupakan bank menyimpan khazanah keilmuan dan budaya dari generasi ke generasi. Namun perpustakaan bukan tempat penyimpanan asesoris keilmuan dan buadaya saja, perpustakaan merupakan ruh yang wajib dimanfaatkan agar roda perputaran kemajuan peradaban berjalan terus.

Seiring masanya peradaban tekonologi, perpustakaan dituntut untuk dapat mengikuti irama kemajuan teknologi di era modern. Perpustakaan tidak hanya menyajikan dalam bentuk manual saja. Perpustakaan dituntut turut serta penyajian layanan dengan irama sistem teknologi dengan berbagai kemudahan dan keuntungan untuk mengakses informasi yang dibutuhkan pengguna. Sisi lain perpustakaan dengan sistem teknologi memberikan keuntungan bagi institusi tersendiri dalam hal perawatan dan pemeliharaan arsip.

Pengembangan perpustakaan dengan sistem teknologi informasi memiliki keuntungan yang banyak. Pengguna dapat berselancar mengakses informasi disemenanjung dunia. Apalagi dalam pengembangan mengkaji budaya antar manusia, perpustakaan sistem informasi teknologi dapat belajar dan mendapatkan informasi multikultural antar bangsa. Kondisi yang demikian menunjukkan dan memberikan makna bahwa setiap orang yang datang di perpustakaan memiliki derajat yang sama untuk mempelajari setiap budaya yang ada di dunia, walaupun 
berbeda latar belakang budaya pengguna. Saling menghargai, dan menghormati untuk mengkaji ilmu pengetahuan yang dibutuhkannya masing-masing pengunjung merupakan niat yang suci dan perlu dihargai bahwa orang tersebut berniat untuk mengembangkan diri dan menjalankan tugas suci yaitu menuntut ilmu dengan cara membaca. Tidak kalah pentingnya lagi bahwa pelayanan yang ramah santun dan meyenangkan dari institusi perpustakaan yang ada di setiap Perguruan Tinggi juga merupakan faktor yang penting untuk mendukung nyamannya pengguna dan kualitas mahasiswa. 


\section{DAFTAR PUSTAKA}

Darmaningtiyas, Perpustakaan dalam Dinamika Pendidikan dan Kemasyarakatan, Ed. F.A. Wiranto, Semarang: Universitas Katolik Soegijapranata, 2008.

Downie, S.J. Realization of Four Important Principles in Cross Cultural Digital Library Development, Originally Presented at The JCDL 03 Workshop, Cross Cultural Usability for Digital Libraries, t.t.

Kim, U., K.S. Yang, dan K.K. Hwang, K.K., Indegenous and Cultural Psychology Understanding People in Context, New York: Springer, 2006.

Nor,Z.M., dan R. Yusuf, "Peranan Perpustakaan dalam Pembentukan Masyarakat yang Kreatif dan Berinovasi”, http://www. myideas.my/, diakses pada 13 Desember 2015.

Purwono dan S. Suharmini, Perpustakaan dan Kepustakawanan Indonesia, Jakarta: Universitas Terbuka, 2009.

Samosir dan Zurni Zahara, "Pengaruh Kualitas Pelayanan terhadap Kepuasan Mahasiswa Menggunakan Perpustakaan USU”, Jurnal Studi Perpustakaan dan Informasi, Vol. 1, No. 1, Juni 2005.

Setyowardani, E., "Membangun Budaya Perpustakaan", Gemari, Edisi 106, Tahun X.

Siregar, A.R., Perpustakaan: Energi Pembangunan Bangsa, Medan: Universitas Sumatra Utara Press, 2003.

Spradley, J.P., Metode Etnografi, Yogyakarta: Mutiara Wacana, 2006.

Sudarsana, U. dan Bastiano, Pembinaan Minat Baca, Jakarta: Universitas Terbuka, 2009.

Triana, Santi, "Analisis Kebutuhan Pengguna Perpustakaan IAIN SU”, Jurnal Iqra, Vol. 7, No. 1, Mei 2013.

Triandis, H.C., "The Self and Social Behavior in Differing Cultural Contexts", Psychological Review, Vol. 96, No. 3, Tahun 1989, hlm. 506-520. 
Umar, T., "Perpustakaan Sekolah dalam Menanamkan Budaya Membaca”, Khizanah al-Hikmah, Vol. 1, No. 2, Tahun 2013, hlm. 123-130.

Undang-undang Republik Indonesia Nomor 43 Tahun 2007 Tentang Perpustakaan.

UNESCO, Universal Declaration on Cultural Diversity, International Federation of Library Associations and Institutions, 2011. 
Saliyo

Halaman ini bukan sengaja dikosongkan 